\title{
DOCUMENTS
}

S. W. Dyer

\section{BUSINESS REACTION TO WATERFRONT UNREST IN THE GREAT DEPRESSION}

In September 1928, the members of the Waterside Workers Federation went on strike, paralysing South Australia's main harbour, Port Adelaide. Their places were taken by men who volunteered to load and unload the ships. When the strike collapsed the Stevedoring Company responsible for hiring workers for the waterfront continued to employ the men whose volunteer labour had broken the strike, in preference to members of the Waterside Workers Federation. Preferential treatment of "volunteers" continued and, as the Depression worsened and unemployment increased, this meant that Union members were less and less likely to get work on the waterfront. Such economic pressure, when combined with an instinctive hatred of the strikebreakers, produced continual clashes between the Unionists and the "volunteers".

The violent incidents of September described in the documents below occurred at a time when one worker in four in South Australia was out of work, and close to half the waterside workers were unemployed. The author of these letters, ${ }^{\mathbf{1}}$ George Cowie, was the manager of the Adelaide branch of the British stock and station company, Dalgety Ltd. He is primarily concerned with reassuring the company's head office in London that all possible efforts are being made to protect the company's wool store at Port Adelaide. At the same time he is careful to explain that the Labor Government is dedicated to the maintenance of order, despite its political colouring. However, his hearty approval of strong, enthusiastic, police action reflects not only the South Australian business community's underlying mistrust of "left-wing" administrations and their deeper fear of Red Revolution, but also the reactions of capitalists everywhere to unrest during the Depression.

1 The letters are held in the Adelaide office of Dalgety Australia Ltd. 


\section{August 1930}

During the last few months assaults have been made on the "volunteer" waterside workers. This morning there was apparently some fairly free rioting at Port Adelaide. Waterside Workers Federation men were picked up to work on a ship with Government cargo, but either failed to present themselves or were two or three hours late arriving at the ship. It is of course impossible to work a vessel under such conditions and the State Committee have suggested to Central Committee $^{1}$ in Melbourne that no Federation men shall be employed until a satisfactory guarantee is given that he will perform the work for which he is engaged. It is stated that the Federation men have assaulted their own secretary. Some windows were broken and a certain amount of damage done but the police are acting firmly. It is a difficult position for a Labour Ministry to handle but we consider they will stand firm. It is nearly two years since the strike which put the Federation men out of their jobs. They have been living on rations and doles ${ }^{2}$ and a certain amount of work that could not be handled by the "volunteers".

\section{Later}

The subscriber has just returned from Port Adelaide. The Union secretaries have lost control of their men, but the real trouble appears to be in the intimidation of those willing to work by others who are unlikely to be offered work. We enclose a pamphlet which is being handed round to the men. It was probably composed by the Communistic section. ${ }^{3}$ We are taking suitable precautions to protect the Company's properties.

\section{September 1930}

\section{WATERSIDE WORKERS}

We cabled you a few days ago for certain extensions of the Strike, Riot and Civil Commotion Risk over the Company's possessions at Port Adelaide. As the newspapers will no doubt have told you of the waterside trouble here we deemed it advisable to cable you last night as follows

"Waterside Workers trouble position quiet but serious

Communists agitating both sides organising"

Port Adelaide yesterday (1st September) was practically in the hands of the Communist section. No one has been able to find out where the

1 Central Committee of the Shipowners Association.

2 The Government "doled" (handed) out food, or coupons which could be exchanged for groceries, to the unemployed.

"This pamphlet" has not survived with the letter, and cannot be traced. 
necessary funds are coming from but it is suspected that they reach Adelaide through Sydney, where the main organisation in Australia exists. Considerable quantities of Russian Petrol are marketed in Australia.

The main roads are freely patrolled by mounted, motor and foot police. ${ }^{1}$ The demonstrators ${ }^{2}$ attempted to prevent vehicles circulating but the police in every case intervened successfully. The most serious and difficult aspect is the intimidation of the men working, and more particularly of their wives and even of their children. There are plenty of men available who would thoroughly enjoy the chance of a good scrap but they hesitate when the punishment may fall upon their dependents. The men in our wool store left work today following similar action in other brokers' stores. They said frankly they went because of their fear for their families and homes.

The Ministry ${ }^{3}$ are quite determined to maintain law and order but they are seriously concerned at the risk of bloodshed, realising that the result of any suppression by arms would react seriously on the State's and probably the Commonwealth's credit. The main argument of the State Committee, i.e. the Overseas and Australian shipowners is that they must not sacrifice the volunteer waterside workers and there is no doubt that they are right in that, for were they to do so it would be a simple and direct method of asking for future trouble.

\section{Later 6/9/30}

The Government introduced a special act entitled "The Preservation of Public Safety Bill" to operate for six months giving them very wide powers to deal with the present commotion. It apparently includes power to do away with the "volunteers" on the wharves. After a fierce fight lasting until the early hours of the morning the Bill was finally passed with an amendment inserted by the Upper House designed to protect the volunteers. A curious addition was accepted to the amendment that the Government could enter into contracts with any stevedoring Company for the purpose of loading or unloading ships. Many people including lawyers hold that this addition would enable the Government to do away with the Volunteers. Such an action after the discussion that took place would be sheer trickery on the Government's part and one can hardly assume that they would go that far. My own impression is that the clause was added to enable the Government to

\footnotetext{
1 At this time about half of the entire South Australian Police force was stationed in and around Port Adelaide.

2 Some 1500 people were involved, approximately $10 \%$ of the workforce in Port Adelaide.

- The Labour Government under Premier Lionel Hill, in office 1930-33.
} 
carry out existing contracts for coal deliveries by sea under which the Government have stipulated that Waterside Workers Federation men shall not be employed. This clause in these contracts was not generally known.

We notified the men in our wool store yesterday that we should expect them to return to work this morning (6th) and they have done so. Our C.O.R. ${ }^{1}$ lorries were the only lorries delivering petrol at Port Adelaide yesterday. They carried three men instead of the usual single driver and were watched by the police. No trouble arose.

A good deal of interest was evinced in a document seized at the Communist headquarters by the police, giving the names of the Premier and other Ministers as among the first to be shot. The police, and particularly the motor police - the bane of the motorist - have done specially good work. They are a fine body of men. We understand that there are a good many headaches about the Port as a result of the payments of old scores by the police. We expect work at the Port to be gradually resumed though there are certain to be some disturbances. Perhaps we should explain that as very few of the volunteers live at the Port the local tradesmen are siding with the waterside workers. Great emphasis is laid on the employment among volunteers of Southern Europeans (about 75 out of 550), but it is rather amusing to realise that the Premier's electorate (Port Pirie) probably includes more foreigners than any other in South Australia.

$11 / 9 / 30$

WATERSIDE WORKERS are still on strike but as there are ample volunteers to carry on the work at the Port no difficulty is being experienced by employers. Some of the men who were engaged as volunteers were actually waterside workers out on strike! We do not anticipate any further trouble at present.

1 For Commonwealth Oil Refineries Ltd., a company backed by the Australian (Federal) Government. 